\title{
In vitro Induction and
}

\section{Characterization of Tetraploid Lychnis senno Siebold et Zucc.}

\author{
Li-ping Chen, ${ }^{1}$ Yan-ju Wang, and Man Zhao \\ DepartmentofHorticulture, College of Agriculture and Biotechnology, Zhejiang \\ University, Hangzhou 310029, China
}

Additional index words. colchicine, tertraploid, mixoploid, flow cytometry, stomata

\begin{abstract}
In this study, in vitro induction of tetraploid Lychnis senno Siebold et Zucc. and its cytological and morphological characterization were conducted. For polyploid induction, nodal segments with axillary buds from in vitro grown plants were kept for 3 days in MS (Murashige and Skoog, 1962) liquid or solid media added with a series of concentrations of colchicine. Out of total 588 recovered plants, 15 tetraploids and 6 mixoploids determined by flow cytometry analysis were obtained. The tetraploid contained 48 chromosomes, twice the normal diploid number of 24 , as observed under light microscope. The tetraploid plants exhibited much larger but less stomata than diploid plants. Moreover, significant differences in stem height and leaf size between the diploid and tetraploid plants were noted. The tetraploid plants were more compact than diploids.
\end{abstract}

Lychnis senno Siebold et Zucc., belonging to the family of Caryophyllaceae, is an indigenous plant species to China. Its flowers are characteristic bright crimson. However, because of its specific habitat requirement and low productivity, it has a limited commercial use. Our previous work showed that $L$. senno can be conserved genetically and propagated by tissue culture, and the botanical characteristics of this species could be modified through tissue culture (Chen et al., 2006). The plants obtained from in vitro culture are shorter in height and produce more flowers, in a range of 15 to 20 per plant, compared with the wild plant. Their flowering duration can be extended from June to November. Thus, the plants with such modified traits are considered to be of great ornamental value. However, they have the defects for potted or landscape utilization because of their thin and long stems.

It has been reported that polyploid horticultural crops possess favorable characteristics such as much larger and heavily textured flowers, more compact growth habit (Eeckhaut et al., 2004), sturdiness and high productivity compared with diploid plants (Sanford, 1983). Triploid L. senno has been found in Japan. It is sterile and considered to be derived from dipolod L. senno (Godo et al., 2004). To date, there is no tetraploid L. senno available, which may have a great potential for genetic breeding and practical use of $L$. senno.

Induction of polyploidy in plants has been traditionally accomplished by use of colchicine. Colchicine is known to inhibit the formation of spindle fibers, and effectively arrests mitosis at the anaphase stage (Hancock, 1997). Since chromosome have already multiplied but

Received for publication 27 Jan. 2006. Accepted for publication 4 Mar. 2006. We would like to thank Masahiro Mii from the Laboratory of Plant Cell Technology, Faculty of Horticulture, Chiba University, Japan, for his information on this species.

${ }^{1}$ Corresponding author; e-mail chenliping@zju. edu.cn. cell division is arrested, polyploid cells are created. The in vitro induction of polyploids with colchicines has been reported in many plant species (Blakesley et al., 2002; Kadota and Niimi, 2002), and in vitro approach can generate more polyploids with higher efficiency than in vivo treatments (Takamura and Miyajima, 1996).

The purpose of the present study was to improve the ornamental qualities of $L$. senno by means of in vitro polyploidization. The cytological and morphological characteristics of polyploids were further studied compared with the diploids.

\section{Material and Methods}

Plant materials. The shoots of $L$. senno Siebold et Zucc. grown on MS medium supplemented with $2.22 \mu \mathrm{M}$ BA and $0.27 \mu \mathrm{M}$ NAA were used as the materials in this study. Nodal segments with axillary buds from these shoots were collected and pre-cultured on MS medium supplemented with $2.22 \mu \mathrm{M}$ BA and $0.27 \mu \mathrm{M}$ NAA for a week, and then were subjected to colchicine treatment either in MS liquid or solid media. 36 nodal segments were treated for each colchicines treatment. All the media used in the present study contained $0.8 \%$ agar and 3\% sucrose except that the liquid one contained no agar.

Colchicine treatment in liquid medium. The nodal segments precultured for a week were transferred to the liquid MS medium with 3\% sucrose comprised of different concentrations of colchicine $(0,0.25,0.5,0.75,1.00$, and 1.25 $\mu \mathrm{M})$. The shoot segment cultures were kept on a shaker constantly shaking at $150 \mathrm{rpm}$ at 28 ${ }^{\circ} \mathrm{C}$ in the dark for $3 \mathrm{~d}$.

Colchicine treatment in solid medium. The nodal segments obtained as previously described were transferred onto solid medium containing different concentrations of colchicine $(0,0.25,0.5,0.75,1.00$, and $1.25 \mu \mathrm{M})$. They were kept in the dark at $28{ }^{\circ} \mathrm{C}$ for $3 \mathrm{~d}$.
Rooting of the regenerants. After colchicine treatment, the explants were all transferred to solid MS medium containing $2.22 \mu \mathrm{M}$ BA and $0.27 \mu \mathrm{M}$ NAA for shoot induction with white fluorescent lights $\left(84 \mu \mathrm{mol} \cdot \mathrm{m}^{-2} \cdot \mathrm{s}^{-1}\right)$ under 16 $\mathrm{h}$ light and $8 \mathrm{~h}$ dark photoperiod at $25^{\circ} \mathrm{C}$. The generated microshoots were then transferred onto a rooting medium (MS with $2.68 \mu \mathrm{M}$ NAA) for rooting.

Flow cytometry analysis. A modified procedure of flow cytometry analysis, based on the method of Otto and Dolezel (Otto, 1990; Dolezel and Göhde, 1995), was employed to analyze DNA relative contents in the regenerants. A fully expanded leaf piece (about 20 $\mathrm{mg}$ ) from each regenerant was chopped with a sharp scalpel in $1 \mathrm{~mL}$ of ice-cold Otto I buffer in a plastic petri dish for nucleus extraction. After filtered through $30 \mu \mathrm{m}$ nylon mesh, the crude nucleus solution was centrifuged at 2000 rpm for $5 \mathrm{~min}$ at $4{ }^{\circ} \mathrm{C}$. The supernatant was removed except $100 \mu \mathrm{L}$ of the liquid above the pellet. The pellet was resuspended by gentle shaking and then $100 \mu \mathrm{L}$ of fresh Otto I buffer was added. After 5 min incubation at room temperature, $500 \mu \mathrm{L}$ of Otto II buffer and $200 \mu \mathrm{L}$ PI (propidium iodide + RNase) staining solution were added and the mixture was gently mixed. DNA content measurement was performed 5 min later with the FACS Calibur system equipped with the program of Cell Quest Pro. For each sample, at least 8000 to 10000 nuclei were analyzed. The relative nuclei DNA contents were presented on semilogarithmic scale histograms. The peak height denoted the relative number of nuclei at each ploidy level. ModFit LT software was used to analyze the data.

Chromosome observation. Root tips were excised from plantlets that were previously analyzed by flow cytometry. The collected root tips were pretreated with $2 \mathrm{~mm} 8$-hydroxyquinoline for $3 \mathrm{~h}$ at $22{ }^{\circ} \mathrm{C}$, and fixed with Carnoy's solution for $24 \mathrm{~h}$. Then they were rinsed with distilled water, hydrolyzed for $8 \mathrm{~min}$ at $60^{\circ} \mathrm{C}$ in $1 \mathrm{~N} \mathrm{HCl}$, squashed under glass cover and stained with acetum magenta. The chromosome number of each sample was microscopically examined.

Stomata observation. The fully expanded leaves were excised from the diploid (as control), mixoploid (chimera) and tetraploid plants grown in a greenhouse. A few strips of epidermis were torn off, and then mounted on a microscope slide with a drop of distilled water and a cover slip to observe stomata frequency and size (Sari et al., 1999).

Statistical analysis. Experimental data were subjected to one or two-way analysis of variance (ANOVA). Fisher's LSD test was applied for means comparison. In both cases a difference was considered statistically significant, only $P<0.05$ and significant differences were denoted in tables by different letters. The treatments were arranged in a completely randomized design with three replicates per treatment.

\section{Results}

Induction of polyploids. The nodal segments 
Table 1. Induction of Lychnis senno polyploids with different concentrations of colchicine in liquid and solid media. ${ }^{2}$

\begin{tabular}{lcccc}
\hline Medium & $\begin{array}{c}\text { Colchicine } \\
\text { concn } \\
(\mu \mathrm{M})\end{array}$ & $\begin{array}{c}\text { Survival } \\
\text { rate } \\
(\%)\end{array}$ & $\begin{array}{c}\text { Mixoploid } \\
(2 \mathrm{x}+4 \mathrm{x})\end{array}$ & $\begin{array}{c}\text { Tetraploid } \\
(4 \mathrm{x})\end{array}$ \\
\hline Solid & 0 & $100.0 \pm 0 \mathrm{a}^{\mathrm{y}}$ & $0(0 \pm 0) \mathrm{b}$ & $0(0 \pm 0) \mathrm{b}$ \\
& 0.25 & $75.0 \pm 0 \mathrm{~b}$ & $0(0 \pm 0) \mathrm{b}$ & $1(2.78 \pm 3.93) \mathrm{b}$ \\
& 0.5 & $58.3 \pm 11.79 \mathrm{c}$ & $0(0 \pm 0) \mathrm{b}$ & $1(2.78 \pm 3.93) \mathrm{b}$ \\
& 0.75 & $50.0 \pm 0 \mathrm{c}$ & $0(0 \pm 0) \mathrm{b}$ & $2(5.56 \pm 3.93) \mathrm{b}$ \\
Liquid & 1 & $58.3 \pm 11.79 \mathrm{c}$ & $1(2.78 \pm 3.93) \mathrm{a}$ & $0(0 \pm 0) \mathrm{b}$ \\
& 1.25 & $50.0 \pm 20.41 \mathrm{c}$ & $1(2.78 \pm 3.93) \mathrm{a}$ & $1(2.78 \pm 3.93) \mathrm{b}$ \\
& 0 & $91.7 \pm 11.79 \mathrm{~b}$ & $0(0 \pm 0) \mathrm{b}$ & $0(0 \pm 0) \mathrm{b}$ \\
& 0.25 & $83.3 \pm 11.79 \mathrm{~b}$ & $0(0 \pm 0) \mathrm{b}$ & $1(2.78 \pm 3.93) \mathrm{b}$ \\
& 0.5 & $66.7 \pm 11.79 \mathrm{~b}$ & $1(2.78 \pm 3.93) \mathrm{a}$ & $4(11.11 \pm 3.93) \mathrm{a}$ \\
& 0.75 & $58.3 \pm 11.79 \mathrm{c}$ & $1(2.78 \pm 3.93) \mathrm{a}$ & $1(2.78 \pm 3.93) \mathrm{b}$ \\
& 1 & $66.7 \pm 11.79 \mathrm{~b}$ & $2(5.56 \pm 3.93) \mathrm{a}$ & $4(11.11 \pm 3.93) \mathrm{a}$ \\
& 1.25 & $58.3 \pm 23.57 \mathrm{c}$ & $0(0 \pm 0) \mathrm{b}$ & $1(2.78 \pm 3.93) \mathrm{b}$ \\
\hline
\end{tabular}

${ }^{\mathrm{z}}$ Figures in parentheses are the percentage of mixoploids or tetraploids.

${ }^{y}$ Means (in the same column) followed by the same letter did not have significant difference by Fisher's protected LSD at $P=0.05$. The treatments were designed with three replications per treatment and 12 shoots were used per replication.
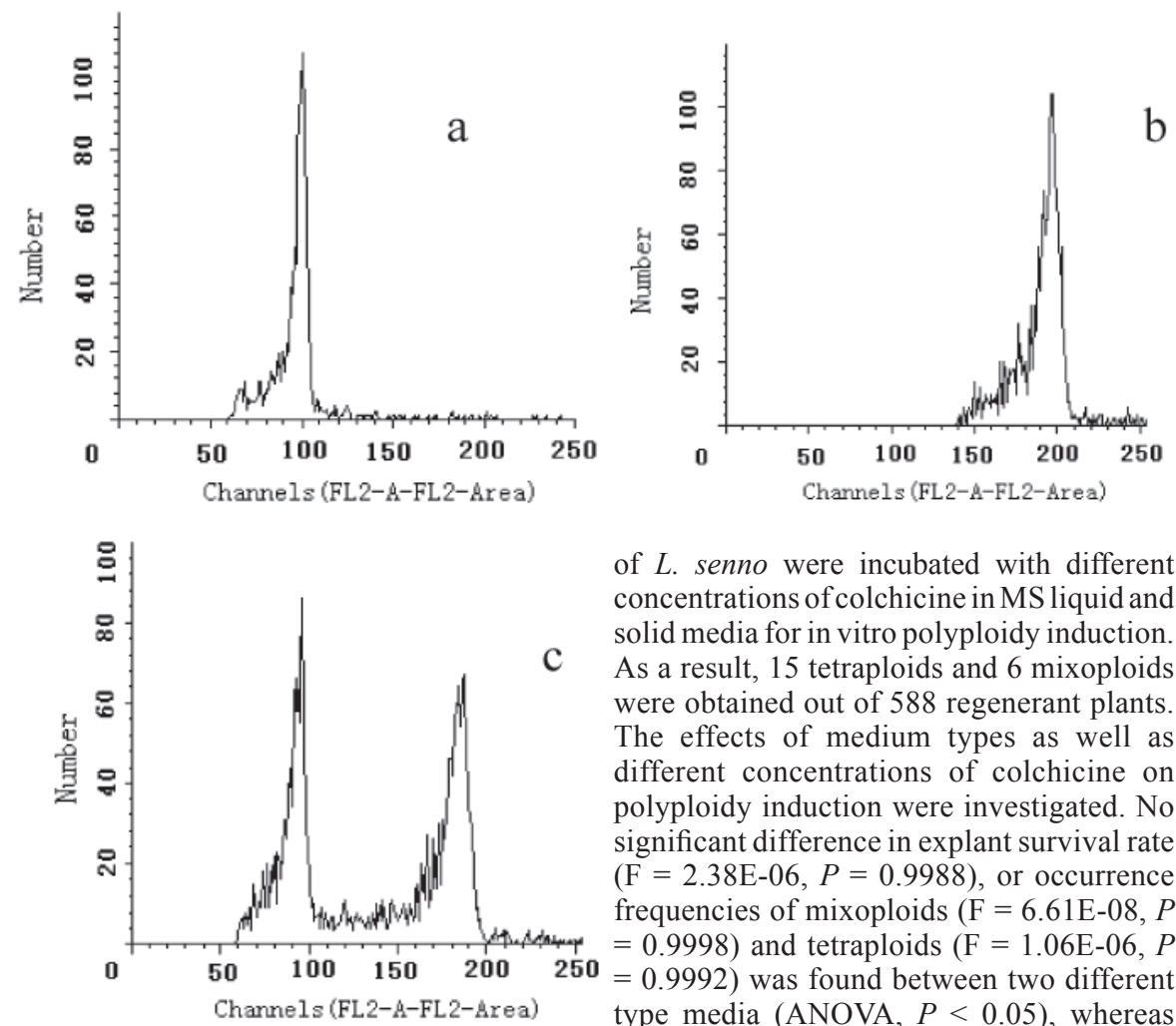

Fig. 1. Comparison of $L$. senno polyploid by flow cytometric histograms. (a) diploid, (b) tetraploid, (c) mixpoploid. X-axes = DNArelative contents; Y-axes $=$ number of nuclei.
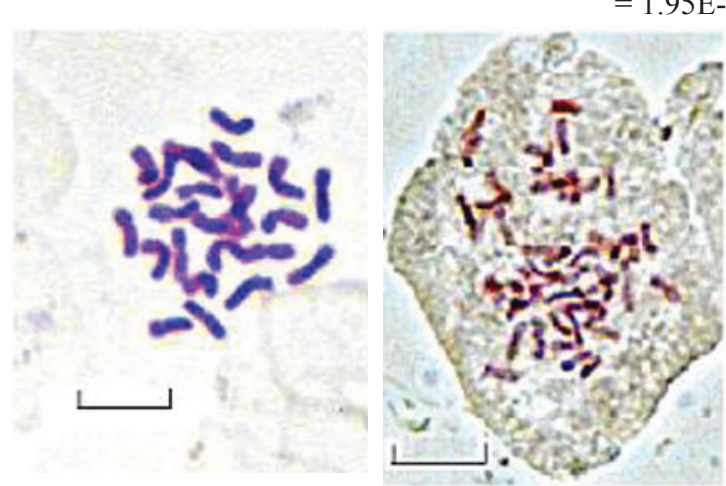

of L. senno were incubated with different concentrations of colchicine in MS liquid and solid media for in vitro polyploidy induction. As a result, 15 tetraploids and 6 mixoploids were obtained out of 588 regenerant plants. The effects of medium types as well as different concentrations of colchicine on polyploidy induction were investigated. No significant difference in explant survival rate (F $=2.38 \mathrm{E}-06, P=0.9988)$, or occurrence frequencies of mixoploids $(\mathrm{F}=6.61 \mathrm{E}-08, P$ $=0.9998)$ and tetraploids $(\mathrm{F}=1.06 \mathrm{E}-06, P$ $=0.9992)$ was found between two different type media (ANOVA, $P<0.05$ ), whereas different colchicine concentrations exhibited significant effects on explant survival rate $(\mathrm{F}$ $=21.3120, P=2.0782 \mathrm{E}-08)$ and occurrence frequencies of mixoploids $(\mathrm{F}=21.4262, P$ $=1.95 \mathrm{E}-08)$ and tetraploids $(\mathrm{F}=21.4198, P$ $=1.95 \mathrm{E}-08)$. Along with increasing colchicine concentrations the survival rate decreased but the induction rate of polyploids increased. Table 1 showed that $1.00 \mu \mathrm{M}$ colchicine solution in liquid medium induced a higher percentage of polyploid plants than the other concentrations.

Flow cytometry analysis. Plant polyploidy was first analyzed by flow cytometry, which has been widely used for measuring DNA content in plant cells or nuclei.

Fig. 2. Chromosomes of $L$. senno tetraploid and diploid; (a) diploid, (b) tetraploid. Bar $=0.01 \mathrm{~mm}$.
The peak of tetraploid was on channel about 200 (Fig. 1b). However, in Fig 1c, the mosaic clearly showed two peaks on the channel 100 and 200, indicating the presence of mixoploids resulted from colchicine treatments. The channels in these histograms were related to DNA contents in plant nuclei.

Chromosome verification. Chromosome numbers of the root tips were observed under a microscope to confirm the flow cytometry results. It showed that the tetraploid contained 48 chromosomes (Fig. 2b), twice the normal diploid number of 24 (Fig. 2a).

Stomatal observation. Stomatal density and sizes of diploid, mixoploid, and tetraploid plants were observed. The results showed that there was a remarkable difference in stomatal density $(F=20.7362, P=4.81 \mathrm{E}-05)$ among these plants. Diploid plants had more stomata $(9.8 /$ view) than polyploids (mixoploid 7.5, tetraploid 4.8). Compared with the diploids, tetraploids had bigger stomatal areas (Fig. 3).

Plant phenotypes. Phenotypes of all the plants grown in greenhouse for 5 weeks were studied (Table 2). Significant differences in plant height $(F=3.5747, P=0.0493)$ and leaf length $(F=8.5230, P=0.0027)$ were found among the plants. The polyploids were shorter than the diploids (Fig. 4a and b). The leaves of the tetraploids were shorter and wider than those of diploids (Fig. 4c and d). Furthermore, the flower diameter of tetraploid was $1.0 \mathrm{~cm}$ larger than that of diploid with similar flower structure and contorted staminal filaments (Fig.4e and f).

\section{Discussion}

A high frequency of mixoploid occurrence is often associated with colchicine (Ackerman and Derman, 1972; Schifino and Fernandes, 1987). Because this alkaloid works effectively only upon dividing cells, thus the polyploidization generally does not equally occur in all explant cells, leading to the occurrence of mixoploids and chimeras (Wan et al., 1989). For instance, only mixploids were induced after colchicines treatment in Pyrus species. The tetraploid shoots were obtained by selection from vegetatively propagating axillary shoots of the mixoploid individuals which have mixed diploid and tetraploid cells. Petersen et al. (2002) reported that colchicines treatment of in vitro shoots only resulted in few tetraploids and a relative high percentage of ploidy chimeras. However, in the present study, both of the mixoplpid and tetraploid shoots were induced with high frequency tetraploid and low mixoploid after colchicine treatment. Therefore, the approach of colchicine is genotype dependent. Nodal segments were considered to be suitable explant for tetraploid induction by colchicine treatment in L. senno.

Stomatal length is an effective indicator for polyploid plant screening because of the simplicity and convenience of stomatal observation (Kadota and Niimi, 2002; Tan and Dunn, 1973; Thomas et al., 2000) before flow cytometric and chromosome analysis. 


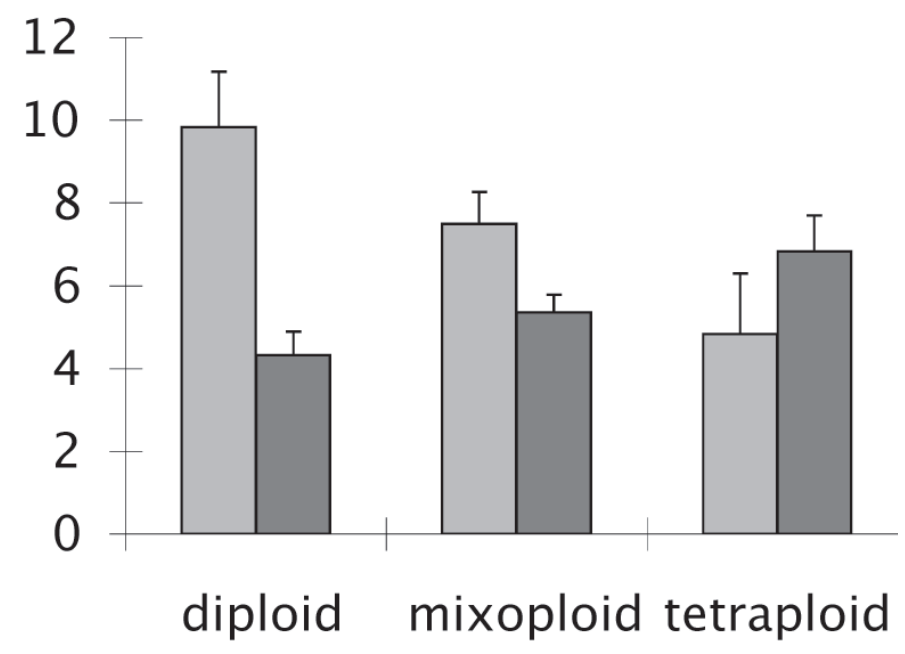

Fig. 3. Stomatal densities and areas of diploids, mixoploid and tetraploids. Means in a column followed by the same letter do not differ and differ significantly if followed by different letters at $P=0.05$. Tests of significance were performed by Fisher's protected LSD. The treatments were arranged in a completely randomized design with three replications per treatment and three microscopic views per replicate (area unit $\times 102$ ). Every view was $140 \times 94 \mu \mathrm{m}$ in size. Left bars $=$ density, right bars $=$ area .

Table 2. Plant phenotypes of polyploids and diploids in Lychnis senno. Plants were investigated in a completely random way with three replications per samples and 12 plants were used for each sample. Data were subjected to one or two-way analysis of variance (ANOVA).

\begin{tabular}{lccccc}
\hline Sample & $\begin{array}{c}\mathrm{Ht} \\
(\mathrm{cm})\end{array}$ & $\begin{array}{c}\text { Leaf } \\
\text { no. }\end{array}$ & $\begin{array}{c}\text { Leaf } \\
\text { length } \\
(\mathrm{cm})\end{array}$ & $\begin{array}{c}\text { Leaf } \\
\text { width } \\
(\mathrm{cm})\end{array}$ & $\begin{array}{c}\text { Leaf area } \\
\text { length } \times \text { width } \\
\left(\mathrm{cm}^{2}\right)\end{array}$ \\
\hline Diploid & $17.4 \pm 1.3 \mathrm{a}^{2}$ & $8.8 \pm 0.7 \mathrm{a}$ & $5.0 \pm 0.3 \mathrm{a}$ & $1.7 \pm 0.1 \mathrm{a}$ & $8.6 \pm 1.3 \mathrm{a}$ \\
Mixoploid & $15.5 \pm 0.4 \mathrm{~b}$ & $8.0 \pm 0.8 \mathrm{a}$ & $5.4 \pm 0.1 \mathrm{a}$ & $1.8 \pm 0.2 \mathrm{a}$ & $9.7 \pm 1.0 \mathrm{a}$ \\
Tetraploid & $14.1 \pm 1.4 \mathrm{~b}$ & $8.0 \pm 1.0 \mathrm{a}$ & $4.3 \pm 0.5 \mathrm{~b}$ & $1.9 \pm 0.2 \mathrm{a}$ & $8.2 \pm 1.7 \mathrm{a}$ \\
\hline
\end{tabular}

${ }^{2}$ Means (in the same column) followed by the same letter did not have significant difference by Fisher's protected LSD at $P=0.05$.
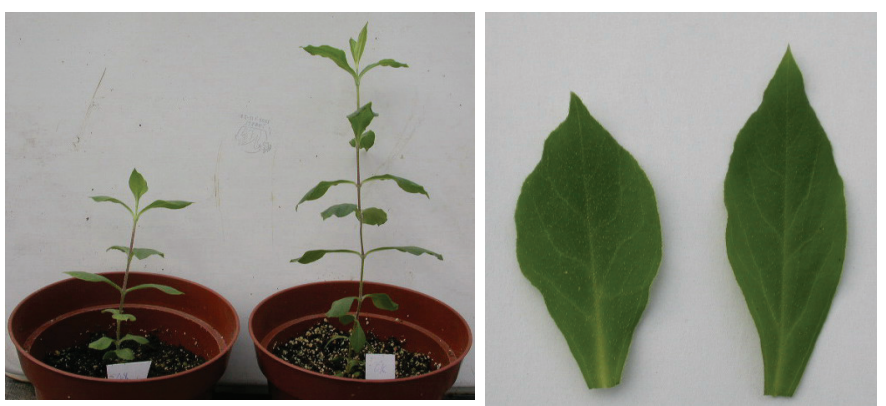

Fig. 4. The morphological characteristics of tetraploids and diploids; (a) tetraploid plantlet, (b) diploid plantlet, (c) tetraploid leaf, (d) diploid leaf, (e) tetraploid flower, (f) diploid flower.
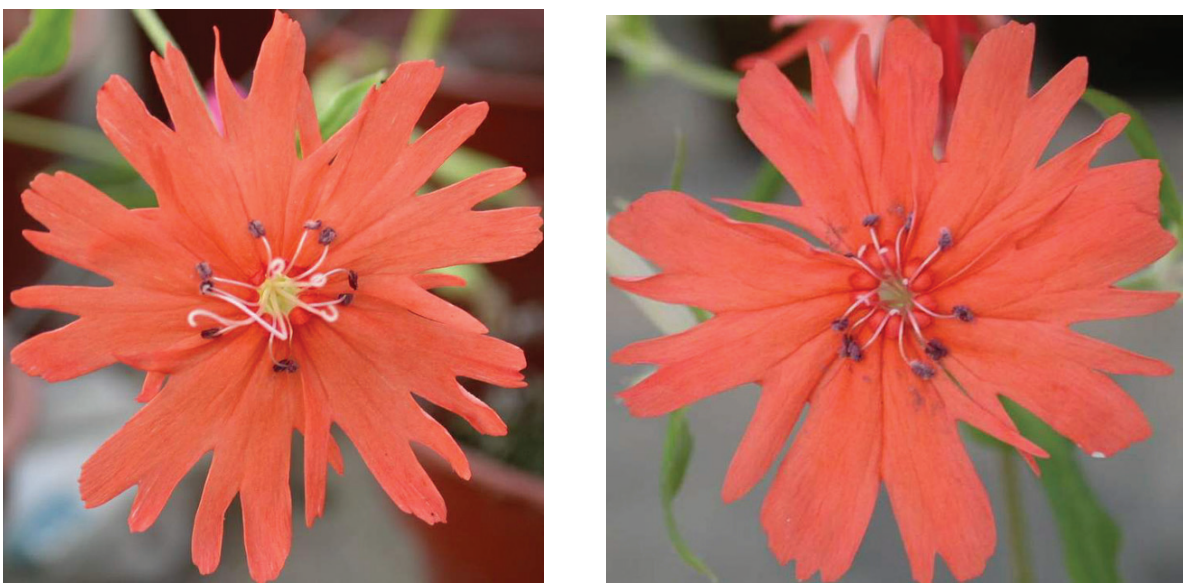

\section{Literature Cited}

Ackerman, W.L. and H. Derman. 1972. A fertile colchiploid from a sterile interspecific camellia hybrid. J. Hered. 63:55-59

Blakesley, D., A. Allen, T.K. Pellny, and A.V. Roberts. 2002. Natural and induced polyploidy in Acacia dealbata Link. and Acacia mangium Willd. Ann. Bot. (Lond). 90(3):391-398

Chen, L., Y. Wang, C. Xu, M. Zhao, and J. Wu. 2006. In vitro propagation of Lychnis senno Siebold et Zucc., a rare plant with potential ornamental value. Sci. Hort. 107(2):183-186

Dolezel, J. and W. Göhde. 1995. Sex determination in dioecious plants Melandrium album and $M$. rubrum using high-resolution flow cytometry. Cytometry 19:103-106.

Eeckhaut, T., S. Werbrouck, L. Leus, E. Van Bockstaele, and P. Debergh. 2004. Chemically induced polyploidization in Spathiphyllum allisii Regel through somatic embryogenesis. Plant Cell Tiss. Org. Cult. 78(3):241-246.

Godo,T., T. Oku, M. Mii, and M. Nakata. 2004. Triploid property of Senno (Lychnis senno Siebold et Zucc., Caryophyllaceae), a traditional ornamental plant conserved in Japan. Breed. Sci. 54:105-109.

Hancock, J. 1997. The colchicine story. HortScience 32:1011-1012.

Kadota, M. and Y. Niimi. 2002. In vitro induction of tetraploid plants from a diploid Japanese pear cultivar (Pyrus pyrifolia N. cv. Hosui). Plant Cell Rpt. 21:282-286.

Murashige, T. and F. Skoog. 1962. Arevised medium for rapid growth and bioassays with tobacco tissue culture. Physiol. Plant 15:473-497.

Otto, F. 1990. DAPI staining of fixed cells for high-resolution flow cytometry of nuclear DNA, p. 105-110. In: H.A. Crissman and Z. Darzynkiewicz (eds.). Methods in cell biology. vol. 33. Academic Press, New York.

Petersen, K.K., P. Hagberg, and K. Kristiansen. 2002. In vitro chromosome doubling of Miscanthus sinensis. Plant Breed. 121:445-450.

Sanford, J.C. 1983. Ploidy manipulations, p. 100-123. In: J.N. Moore and J. Janick (eds.). Methods in fruit breeding. Purdue Univ. Press, West Lafayette.

Sari, N., K. Abak, and M. Pitrat. 1999. Comparison of ploidy level screening methods in watermelon: Citrullus lanatus (Thunb.) Matusum and Nakai. Sci. Hort. 82:265-277.

Schifino, M.T. and M.I.M. Fernandes. 1987. Induction of polyploidy and cytological characterization of autotetraploids of rifolium riogradense Burkart (Leguminosae). Euphytica $36: 863-872$.

Takamura, T. and I. Miyajima. 1996. Colchcine induced tetraploids in yellow flowered cyclamens and their characteristics. Sci. Hort. 65:305-312.

Tan, G.Y. and G.M. Dunn. 1973. Relationship of stomatal length and frequency and pollen-grain diameter to ploidy level in Bromus inermis Leyss. Crop Sci. 13:332-334.

Thomas, T.D., A.K. Bhatnagar, and S.S. Bhojwani. 2000. Production of triploid plants of mulberry (Morus alba L. ) by endosperm culture. Plant Cell Rpt. 19:395-399.

Wan, Y., J.F. Petolino, and J.M. Widholm. 1989. Efficient production of doubled haploid plants through colchicine treatment of antherderived maize callus. Theor. Appl. Genet. 77:889-892. 